\title{
PERAN PENDIDIK DALAM MENGATASI PERMASALAHAN PERTUMBUHAN DAN PERKEMBANGAN PESERTA DIDIK
}

\author{
Ramlan Setiawan \\ SDN Sumpinghayu Cilacap \\ ang_eloncakep@hotmail.com
}

\begin{abstract}
Growth can be defined as an increase in size (physical) or quantitative changes in material as a result of environmental influences. This quantitative change can be an enlargement or increase from nothing to exist, from small to large, from little to many and so on. The development is a process of qualitative change that refers to the quality of the functioning of physical organs, not the physical organs themselves. In other words, the emphasis of the meaning of development lies in the improvement of psychological functions carried by physical organs. This research analysis technique involves interpretation using a qualitative approach (critical reasoning). So the development of students is indeed in a transition period from childhood to adolescence and from adolescence to adulthood can be concluded by it. At that time, students go through a period called adolescence or puberty which very vulnerable to the temptations that come. Starting from the temptation of women so that many adolescents who are weak in faith engaging in extramarital relations, rampant drugs and alcohol damage young people.
\end{abstract}

Keywords: teacher role, growth problems, student development process.

\section{Pendahuluan}

Sistem yang dianut pada saat ini bukan lagi sistem pendidikan yang dimaksudkan sebagai upaya mencerdaskan kehidupan bangsa, tetapi menjadi sebuah usaha yang menciptakan kesadaran. Stimulus menjadi sebuah teori yang sedari lama digunakan dalam proses KBM. 
Teori ini menyebabkan pembelajar pasif. Reinforcement pada suatu perilaku tertentu dapat terbentuk dan akan menghilang bila dikenai hukuman (Budiningsih, 2005, p. 4). Inilah yang terjadi di dunia pendidikan Indonesia, pendidikan hanya berorientasi pada hasil dan nilai akhir, dikarenakan pendidikan hanya transfer of knowledge tanpa dibarengi dengan transfer of value. Faktanya bisa kita lihat di sekitar kita, peserta didik tidak mengaplikasikan tujuan pendidikan tersebut, akhirnya banyak peserta didik yang melakukan tawuran antar sekolah, penyalahgunaan narkoba dan lain-lain.

Dalam paparan tersebut, penulis akan menjelaskan bagaimana peran seorang guru khususnya guru PAI dalam meminimalisir perilaku asosial, sehingga tujuan pendidikan akan teraplikasikan dengan baik.

\section{Pembahasan}

\section{Pengertian Pertumbuhan dan Perkembangan}

Istilah perkembangan dalam bidang psikologi merupakan suatu konsep yang cukup kompleks. Hal ini dikarenakan terdapat banyak dimensi dan untuk dapat memahaminya, kita harus dapat membedakan pengertian pertumbuhan dan perkembangan (Desmita, 2009, p. 8). Pertumbuhan dapat didefinisikan sebagai peningkatan dalam ukuran (fisik) atau perubahan yang secara signifikan terlihat pada materil sesuatu sebagai akibat dari rangsangan atau stimulus dari lingkungan sekitar. Perubahan ini dapat berupa pembesaran atau pertambahan dari tidak ada menjadi ada, dari kecil menjadi besar, dari sedikit menjadi banyak dan sebagainya. Sedangkan perkembangan didefinisikan sebagai kemajuan menuju kedewasaan.

Pertumbuhan secara kuantitatif berarti perubahan yang pada jumlah, besar, dan luas yang bersifat konkret mengacu pada perubahan. Pembesaran atau penambahan seperti: dari kecil menjadi besar, dari pendek menjadi panjang merupakan manifestasi dari perubahan, begitu halnya dalam peristiwa, dari sempit menjadi luas, dan lain-lain. Hal ini dapat diartikan pertumbuhan berarti kenaikan dan penambahan ukuran dengan proses yang berubah secara berkala. Sedang perubahan yang secara kualitatif mengacu pada kualitas fungsi 
organ jasmani adalah perkembangan (Muhibbin syah, 2010, p. 41-42).

Dalam penggunaannya, kata pertumbuhan dan perkembangan digunakan secara bersama-sama untuk menggambarkan prosesproses fisik, mental, dan emosional yang komplek yang terkait dengan tumbuh kembangnya peserta didik (Denim, 2010, p. 8). Bila perubahan berkenaan dengan aspek-aspek fisik lahir yang nampak maka kesulitan yang dihadapi oleh pihak yang berkepentingan tidak terlalu menghambat, namun yang berhubungan dengan aspek psikis kita harus mencari tanda-tanda atau manifefstasi-manifestasi yang bisa diamati.

Secara garis besar tanda-tanda individu yang berkenaan dengan fisik maupun psikis anatara lain:

a) Perubahan yang tampak seperti bertambahnya ukuran atau berat pada anggota badan atau badan itu sendiri.

b) Perubahan yang terdapat dalam psikis seperti pengendalian emosional, perubahan pada perilaku.

Selain itu individu juga mengalami pergantian ciri-ciri lama misalnya ukuran diameter kepala mengalami pergantian menjadi lebih besar. Demikian pula peristiwa-peristiwa psikis yang berhubungan dengan kejiwaan individu seperti fantasi, perasaan, sikap periode anak-anak dengan datangnnya masa remaja, dan seterusnya.

Tabel 1. Perbedaan pertumbuhan dan perkembangan

\begin{tabular}{|c|l|l|}
\hline No. & \multicolumn{1}{|c|}{ PERTUMBUHAN } & \multicolumn{1}{c|}{ PERKEMBANGAN } \\
\hline 1 & $\begin{array}{l}\text { Cenderung lebih bersifat } \\
\text { kuantitatif dan berkaitan } \\
\text { dengan aspek fisik. }\end{array}$ & $\begin{array}{l}\text { Cenderung lebih bersifat kualitatif, } \\
\text { berkaitan dengan pematangan } \\
\text { mental atau rohani. }\end{array}$ \\
\hline 2 & $\begin{array}{l}\text { Berlansung pada suatu titk } \\
\text { optimum dan kemudian } \\
\text { menurun menuju pada } \\
\text { keryntuhannya. }\end{array}$ & $\begin{array}{l}\text { Perkembangan rohani tidak } \\
\text { terhambat walaupun keadaan } \\
\text { jasmani sudah sampai pada puncak } \\
\text { pertumbuhannya. }\end{array}$ \\
\hline
\end{tabular}




\begin{tabular}{|c|l|l|}
\hline No. & \multicolumn{1}{|c|}{ PERTUMBUHAN } & \multicolumn{1}{c|}{ PERKEMBANGAN } \\
\hline 3 & $\begin{array}{l}\text { Contohnya ukuran berat dan } \\
\text { tinngi badan ukuran dimensi } \\
\text { sel tubuh, dan umur tulang. }\end{array}$ & $\begin{array}{l}\text { Contohnya bertambahnya } \\
\text { kemampuan dalam perkembangan } \\
\text { bahasa, emosi, intelektual, dan } \\
\text { perilaku sebagai kemampuan } \\
\text { dalam mengatur struktur dan } \\
\text { fungsi tubuh yang lebih kompleks } \\
\text { dengan pola yang teratur }\end{array}$ \\
\hline No. & PERTUMBUHAN & PERKEMBANGAN \\
\hline 1 & $\begin{array}{l}\text { Cenderung lebih bersifat } \\
\text { kuantitatif dan berkaitan } \\
\text { dengan aspek fisik. }\end{array}$ & $\begin{array}{l}\text { Cenderung lebih bersifat kualitatif, } \\
\text { berkaitan dengan pematangan } \\
\text { mental atau rohani. }\end{array}$ \\
\hline 2 & $\begin{array}{l}\text { Berlansung pada suatu titk } \\
\text { optimum dan kemudian } \\
\text { menurun menuju pada } \\
\text { keryntuhannya. }\end{array}$ & $\begin{array}{l}\text { Perkembangan rohani tidak } \\
\text { terhambat walaupun keadaan } \\
\text { jasmani sudah sampai pada puncak } \\
\text { pertumbuhannya. }\end{array}$ \\
\hline 3 & $\begin{array}{l}\text { Contohnya ukuran berat dan } \\
\text { tinngi badan ukuran dimensi } \\
\text { sel tubuh, dan umur tulang. }\end{array}$ & $\begin{array}{l}\text { Contohnya bertambahnya } \\
\text { kemempuan dalam struktur dan } \\
\text { fungsi tubuh yang lebih kompleks } \\
\text { dalam pola yang teratur, misalnyab } \\
\text { dsalam perkembangan bahasa, } \\
\text { emosi, intelektual, dan perilaku. }\end{array}$ \\
\hline
\end{tabular}

Bukuyang berjudu Education Psychology karya H.C. Whetherington, setidaknya terdapat prinsip-prinsip pertumbuhan dan perkembangan yang disampaikan. Akan disebutkan beberapa prinsip yang terkesan lebih menonjol dan dapat dipraktekan secara nyata, diantaranya:

a) Pada tahun-tahun pertama pertumbuhan lebih cepat.

b) Tingkat kedewasaan yang dicapai dapat mempengaruhi usahausaha belajar.

c) Setiap individu mengikuti pola perkembangan umum yang sama.

d) Tempo perkembangan setiap individu berbeda-beda.

e) Sifat-sifat psikis dapat timbul secara bersamaan namun tidak berturut-turut.

f) Hereditet dan lingkungan sangat penting bagi pertumbuhan (Mustaqim, 2008, p. 15).

\section{Perkembangan Peserta Didik}

Para ahli di bidang ilmu psikologi beranggapan bahwa peserta 
didik mengalami karakteristik yang labil. Itu dikarenakan peserta didik berada pada kondisi yang mengalami banyak perubaha mulai dai dari masa anak-anak menuju masa remaja kemudian dari masa remaja menuju masa dewasa. Pada masa itu, peserta didik melalui masa masa pubertas (remaja).

Desmita menurutkan bahwa pencarian jati diri ada pada masa remaja. Hal-hal tersebut ditandai dengan beberapa hal, diantaranyanya:

a) Dapat membangun interaksi yang matang dengan teman sebaya.

b) Mampu menerima dan dapat belajar peran sosial di dalam masyarakat.

c) Menggunakan keadaan fisik dengan efektif dengan kesadaran self acceptance.

d) Belajar dari orangtua dan orang dewasa lainnya untuk mencapai kemandirian emosional.

e) Sesuai dengan passion mampu memilih dan mempersiapkan karir di masa depan.

f) Mengembangkan postive thingking tentang sebuah pernikahan dan kehidupan berumahtangga.

g) Mampu menginovasi keterampilan intelektual dan hal-hal lainnya yang diperlukan sebagai warga Negara.

h) Secara sosial dapat mencapai tingkah laku dan mampu bertanggungjawab.

i) Menetapkan nilai dan etika sebagai pedoman dalam berperilaku.

j) Mengembangkan wawasan keagamaan dan meningkatkan religiusitas.

Kesepuluh karakteristik perkembangan peserta didik di atas memberikan pengaruh dalam perkembangan aspek kognitif, afektif, maupun psikomotor peserta didik sebagai berikut:

\section{Perkembangan Kogniti}

Perkembangan kognitif merupakan kemampuan berfikir atau intelektual. Dengan demikian dapat dikatakan bahwa perkembangan kognitif berkaitan langsung dengan proses pembelajaran. Hal tersebut digambarkan dalam enam tahap yaitu, pengetahuan atau pengenalan, pemahaman, penerapan, analisis, sintesis dan evaluasi. 
Usia peserta didik mendekati efisiensi intelektual yang maksimal, namun karena kurangnya pengalaman sehingga membatasi pengetahuan dan kecakapannya untuk memanfaatkan apa yang diketahui. Banyak yang dapat dipelajari melalui pengalamannya, tetapi mereka kadangkala megalami kesulitan dalam menagkap serta memahami konsep-konsep abstrak dan mungkin mereka belum mampu memahami sepenuhnya. Menurut Bruner, perkembangan kognitif seseorang terjadi melaui tiga tahap yang ditentukan oleh caranya melihat lingkungan, yaitu (Muhaimin, 2002, p. 200):

a) Tahap enaktif, di mana individu melakukan aktivitas dalam upaya memahami lingkungannya.

b) Tahap ekonit, di mana individu melihat dunia melalui gambargambar dan visualisasi verbal.

c) Tahap simbolik, di mana individu mempunyai gagasan-gagasan abstrak yang banyak dipengaruhi bahasa dan logika berfikirnya.

\section{Perkembangan Afektif}

Keberhasilan pengembangan ranah kognitif tidak hanya akan membuahkan kecakapan kognitif, tetapi juga menghasiulkan kecakapan ranah afektif. Sebagai contoh, seorang Guru agama yang piawai dalam mengembangkan kecakapan kognitif dengan cara seperti ini, akan berdampak posotif keranah afektif para siswa. Dalam hal ini, pemahaman yang mendalam terhadap arti penting materi pelajaran agama yang disajikan guru serta preferensi kognitif yang mementingkan aplikasi prinsip-prinsip tadi akan meningkatkan kecakapan ranah afektif para siswa. Peningkapan kecakapan afektif ini, antara lain berupa kesadaran beragama yang mantap.

Kemampuan afektif ini terdiri dari lima tahapan, yaitu pengenalan atau penerimaan, pemberian respon, penghargaan terhadap nilai, pengorganisasian, dan pengalaman

Emosi peserta didik pada saat dewasa sama dengan emosi pada masa anak-anak. Perbedaanya terletak pada rangsangan yang membangkitkan emosi dan juga derajatnya, khususnya terhadap upaya pengendalian diri terhadap emosi mereka. Misalnya, mereka tidak lagi megungkapkan amaranhnya dengan gerakan amarah yang meledak- 
ledak tetapi dengan menggerutu, tidak mau bicara, atau dengan bersuara keras mengkritik orang yang menyebabkan amarahnya tersebut.

\section{Perkembangan Psikomotor}

Keberhasilan pengembangan ranah kognitif juga akan berdampak positif terhadap perkembangan ranah psikomotor. Kecakapan psikomotor adalah segala amal jasmaniah yang konkret dan mudah diamati, baik kuantitasnya maupun kualitasnya, karena saifatnya yang terbuka. Namun kecakapan psikomotor tidak terlepas dari kecakapan afektif. Jadi, kecakapan psikomotor siswa merupakan manifestasi wawasan pengetahuan dan kesadaran serta sikap mentalnya.

Kemampuan psikomotorik ini dibagi menjadi lima tahapan, yaitu meniru, memanipulasi, akurasi gerak, artikulasi dan naturalisasi/ otonomisasi.

\section{Permasalahan Peserta Didik}

Salah satu permasalahan serius yang dihadapi dunia pendidikan sekarang ini adalah rendahnya kualitas pembelajaran, termasuk pembelajaran PAI. Proses pembelajaran pendidikan agama terjadi kerap kali baru bersifat seadanya, rutinitas, formalitas, kering, dan kurang makna. Kualitas semacam itu akan menghasilkan mutu pendidikan agama yang rendah pula.

Beberapa Permasalahan perkembangan peserta didik di masyarakat antara lain:

\section{1) Masalah kesehatan reproduksi dan pacaran}

Kondisi peserta didik yang belum menikah belum berhak mendapatkan informasi maupun pelayanan medis untuk kesehatan reproduksi, hal ini dihukumi secara sosial termasuk agama. Sementara itu, suguhan media masa merangsang libido peserta didik remaja. Hal ini berdampak pada perilaku seksual pranikah yang disertai ketidaktahuan dan dapat membahayakan kesehatan reproduksi mereka.

Menurut Freud, masalah seks (dalam teorinya libido) dalam arti yang luas merupakan dorongan paling pokok dalam diri manusia. Teori ini benar, ditunjang oleh kenyataan. Juga mengenai remaja 


\section{L-Tarbawj Ramman setiawn}

muslim. Remaja senang berpacaran, itu sifat asli mereka, remaja muslim juga senang berpacaran. Dalam hal ini, mereka yang paling baik adalah bersekolah dan jangan berpacaran. Sekali berkenalan sebaiknya langsung nikah (Tafsir, 2004, p. 182).

\section{2) Masalah merokok}

Peserta didik yang digolongkan sebagai perokok berat adalah bila ia mengkonsumsi lebih dari 31 batang rokok perhari dan dengan jeda waktu lima menit setelah bangun pagi. Apabila kita ketahui, rokok mengandung 4000 macam zat yang berbahaya bagi tubuh, diantaranya:
a) Nikotin, kandungan pestisida.
b) Hydrogen sianida, gas mematikan.
c) Tar, campuran aspal.
d) CO, gas beracun.
e) Formalin, bahan pengawet mayat.
f) Arsen, racun yang mematikan.
g) Kodimium, bahan batu baterai.

Setidaknya, secara umum bahaya penghisap rokok terbukti membahayakan kesehatan para perokok aktif dan pasif. Berbagai penyakit akibat rokok:
a) Kanker
b) Penyakit kardiovaskular
c) Impotensi
d) Gangguan saraf
e) Gangguan indera penglihatan, pendengaran, penciuman, pengecap
f) Gangguan pernapasan
g) Gangguan pencernaan
h) Dan lain-lain

Disamping laki-laki, bahaya rokok juga akan dialami perempuan perokok, diantarannya:
a) Gangguan kesuburan
b) Gangguan kehamilan dan janin
c) Resiko keguguranresiko menopause dini

\section{3) Masalah perilaku konsumtif}


Kata konsumtif menjelaskan bahwa beberapa barang yang kurang diperlukan, dikonsumsi secara berlebihan hanya dengan tujuan untuk mencapai kepuasan. Kata tersebut juga memiliki hubungan dengan produsen dan konsumen.

a) Masalah perkelahian atau tawuran antar peserta didik

Perkelahian antar peserta didik juga menyita perhatian di dunia pendidikan zaman sekarang ini. Maraknya aksi tawuran dan kekerasan yang dilakukan oleh peserta didik, seperti peserta didik mulai dari SMP, SMA, SMK sampai perguruan tinggi semakin banyak menghiasi deretan berita dihalaman media cetak maupun media elektronik.

b) Masalah frustasi dan strees

Fenomena stress sekolah yang dirasakan oleh peserta didik juga telah banyak disadari dan menjadi wilayah perhatian yang luas dikalangan ilmuan, peneliti, guru dan pemerintah. Beberapa penelitian menunjukan ada fenomena stress yang berkaitan dengan peristiwa-peristiwa hidup di sekolah. Peserta didik yang mengalami stress disebabkan karena beberapa factor diantaranya:

1) Intensitas belajar yang tinggi

2) Rentang waktu belajar yang lebih lama

3) Tugas-tugas sekolah yang lebih banyak

4) Cemas menghadapi ujian semester maupun ujian nasional

5) Keadaan keluarga yang kurang harmonis dan kurang mendukung terhadap pendidikan peserta didik

6) Kondisi keluarga yang memprihatinkan

c) Masalah narkoba dan miras

Peredaran narkoba dan miras yang semakin merajalela di kalangan pelajar membuat pelajar terkena dampak dari penyalahgunaan narkoba. Apabila kita melihat di media massa dan elektronik banyak dijumpai peserta didik yang tertangkap oleh petugas membawa,memakai dan mengedarkan narkoba dan miras. Biasanya mereka lakukan dengan dalih untuk menghilangkan stress.

Dampak penyalahgunaan miras seperti yang terjadi di kabupaten bandung pada awal-awal tahun 2018 banyak memakan korban sampai kurang lebih 55 orang tewas setelah meneguk 
miras oplosan.

d) Masalah penipuan terhadap orang tua

Penipuan yang dilakukan peserta didik terhadap orang tua banyak sekali terjadi di setiap sekolah. Ini dikarenakan mereka miniru kebobrokan pemerintah yang banyak sekali melakukan tindakan korupsi, padahal hutang Indonesia banyak menumpuk dimana-mana.

Pikiran rakyat (26 Juli 2006) mengemukakan bahwa, Indonesia menjadi penghutang no 6 ditingkat dunia, no 3 sebagai negara terkorup, peringkat SDM ke 112 dari 127 negara, dengan penduduk yang hidup dibawah garis kemiskinan mencapai $30 \%$ dan pengangguran terbuka mencapai 12 juta. Hal tersebut bisa juga diakibatkan oleh faktor politik dan keamanan yang tidak mendukung, penegakan hukum yang tidak konsisten, iklim investasi yang kurang kondusif serta birokrasi pemerintah yang berbelit, disamping semrawutnya menejemen sistem pendidikan nasional, sebagai lembaga yang bertugas menyiapkan SDM.

\section{Peran Pendidik dalam Mengatasi Permasalahan Perkembangan Peserta Didik}

Dalam Islam pendidikatau guru adalah seseorangyang memegang amanah untuk mendidik dan mengajar, serta memiliki peran transfer of knowledge dan transfer of value. Harapannya guru dapat memberikan misi ilmu pengetahuan dengan menyesuaikan perkembangan dan tuntutan masa depan (Ulum, 2007, p. 119).

Guru berperan aktif dalam membantu tugas Negara yakni mencerdaskan kehidupan bangsa dan itu tercantum dalam konstitusi Negara kita. Disisi lain, guru juga sebagai "the second farent" atau orang tua kedua setelah orang tua dirumah.

Seorang guru adalah insan pemberi ilmu. Seorang guru adalah penerang bangsa dan pembangun budaya yang harus dihormati setelah berbakti kepada ibu dan bapak. Diriwayatkan oleh Abu Hasan Mawardi bahwa Nabi SAW berpesan: "muliakanlah orang-orang yang telah memberikan pelajaran kepadamu" (Marijan, 2012, p. 87).

Seorang pendidik tidak hanya mentrasfer keilmuan, tetapi juga 
mentransformasikan nilai-nilai pada peserta didik. Untuk itu, guna merealisasikan tujuan pendidikan, manusia sebagai kholifah yang punya tanggung jawab mengantarkan manusia kearah tujuan tersebut, cara yang ditempuh yaitu menjadikan sifat-sifat Allah sebagai bagian dari kepribadiaanya. Beberapa bentuk nilai-nilai itu adalah nilai etika, pragmatis, nilai effect sensorik dan nilai religius.

Secara umum, tugas pendidik menurut islam adalah mengupayakan perkembangan seluruh potensi subjek didik. Pendidik tidak saja bertugas menstrasfer ilmu, tetapi yang lebih penting dari itu adalah mentrasfer pengetahuan sekaligus nilai-nilai, yang terpenting adalah nilai ajaran islam. Peranan guru adalah terciptanya serangkaian tingkah laku yang saling berkaitan yang dilakukan dalam suatu situasi tertentu serta berhubungan dengan kemajuan perubahan tingkah laku dan perkembangan siswa yang menjadi tujuannya.

Tugas dan peran guru tidaklah terbatas di dalam masyarakat, bahkan guru pada hakikatnya merupakan komponen strategisyang memilih peran yang penting dalam menentukan gerak maju kehidupan bangsa. Bahkan keberadaan guru merupakan faktor condisio sine quanon yang tidak mungkin digantikan oleh komponen manapundalam kehidupan bangsa sejak dulu, terlebih-lebih pada era kontemporer ini (Nurfuadi, 2011, p. 102).

Seorang guru/pendidik dalam melakukan perbaikan pembelajaran pendidikan agama islam harus diawali dari desain pembelajaran yang baik, dengan perkataan lain perancangan pembelajaran pendidikan agama dapat dijadikan titik awal upaya perbaikan kualitas pembelajaran. Hal ini didukung oleh hasil penelitan Chair, yang menunjukan bahwa kegiatan pembelajaran yang diawali dengan melakukan kegiatan penyusunan perencanaan pembelajaran akan meningkatkan kualitas pembelajaran dan meningkatkan perolehan hasil belajar. Dengan demikian, langkah awal dalam upaya meningkatkan kualitas pembelajaran pendidikan agama adalah memperbaiki kualitas pembelajaran pendidikan agama melalui peencanaan pembelajaran yang profesional (Muhaimin, 2002, p. 190).

Peran Pendidik dalam menghadapi Permasalahan perkembangan peserta didik antara lain: 


\section{e-Tarbawj}

a) Memberikan pengetahuan dan pemahaman tentang kesehatan reproduksi, bahaya seks bebas dan penyalahgunaan narkoba serta miras

b) Membantu peserta didik mengembangkan sikap apresiatif terhadap postur tubuh atau kondisi dirinya

c) Memberikan pelatihan untuk mengembangkan ketrampilan memecahkan masalah dan mengambil keputusan

d) Melatih peserta didik mengembangkan resiliensi (kemampuan bertahan dalam kondisi sulit dan penuh godaan)

e) Menjalin hubungan yang harmonis dengan peserta didik dan bersedia mendengarkan keluhan dan problem yang dihadapinya

f) Memupuk spirit keagamaan peserta didik melalui pembelajaran PAI secara humanis dan lebih toleran

g) Menerapkan model pembelajaran PAI yang memungkinkan peserta didik untuk berfikir kritis, reflektif, dan positif

h) Membantu peserta didik mengembangkan etos kerja yang tinggi dan menumbuhkan jiwa kewirausahaan

i) Merumuskan tujuan kurikulum PAI yang mencakup aspek kognitif, afektif, dan psikomotorik

j) Pendidik harus menjadi figur dan tauladan yang baik bagi peserta didiknya

k) Pendidik harus mampu membentuk kepribadian yang sehat bagi peserta didiknya (Nurfuadi, 2011, p. 102)

\section{Kesimpulan}

Dari paparan diatas, dapat disimpulkan bahwa Pertumbuhan dapat didefinisikan sebagai peningkatan dalam peningkatan ukuran (fisik) atau perubahan yang secara signifikan terlihat pada materil sesuatu sebagai akibat dari rangsangan atau stimulus lingkungan sekitar. Perubahan ini dapat berupa pembesaran atau pertambahan dari tidak ada menjadi ada, dari kecil menjadi besar, dari sedikit menjadi banyak dan sebagainya. Sedangkan perkembangan didefinisikan sebagai kemajuan menuju kedewasaan.

Perkembangan individu dari masa anak-anak menginjak ke remaja dan dari remaja menginjak ke dewasa. Pada masa itu, peserta 
didik melalui masa remaja. Masa remaja ini rentan sekali akan godaan yang datang, mulai dari godaan perempuan sehingga banyak para remaja yang tidak kuat imannya melakukan hubungan di luar nikah, maraknya narkoba dan miras mengintai para pemuda dengan meksud untuk merusak generasi muda bangsa.

\section{Daftar Pustaka}

Budiningsih, Asri. (2005). Belajar dan Pembelajaran. Jakarta: Rineka Cipta.

Denim, Sudarwan. (2010). Perkembangan Peserta Didik. Bandung: Alfabeta.

Desmita. (2009). Psikologi Perkembangan. Bandung: Rosdakarya.

Marijan. (2012). Metode Pendidikan Anak Membangun Karakter Anak Yang Berbudi Mulia, Cerdas Dan Berprestasi. Yogyakarta: Sabda Media.

Muhaimin. (2002). Paradigma Pendidikan Islam Upaya Mengefektifkan Pendidikan Agama Islam Di Sekolah. Bandung: Remaja Rosdakarya. Mulyasa. (2007). Kurikulum Tingkat Satuan Pendidikan. Bandung: Rosdakarya.

Mustaqim. (2008). Psikologi Pendidikan. Yogyakarta: Pustaka Pelajar.

Nafis, Muhammad Muntahibun. (2011). Ilmu Pendidikan Islam. Yogyakarta: Teras.

Nurfuadi. (2011). Kepribadian Guru. Purwokerto: STAIN Press.

Roqib, Mohammad. (2009). Ilmu Pendidikan Islam. Yogyakarta: Lkis Printing Cemerlang.

Satiti, Alfi. (2009). Strategi Rahasia Berhenti Merokok. Yogyakarta: Datamedia.

Soemanto, Wasty. (2006). Psikologi Pendidikan Landasan Kerja Pemimpin Pendidikan. Jakarta: Rhineka Cipta.

Syah, Muhibbin. (2010). Psikologi Pendidikan Dalam Pendekatan Baru. Bandung: Remaja Rosdakarya.

Tafsir, Ahmad. (2004). Ilmu Pendidikan Islam Dalam Perspektif Islam. Bandung: Remaja Rosdakarya.

Ulum, Miftahul dan Basuki. (2007). Pengantar Ilmu Pendidikan Islam. 


\section{eL-Tarbawj Ramlan Setiawan}

Ponorogo: STAIN Po Press.

Usman, Moh Uzer. (1997). Menjadi Guru Professional. Bandung: Rosdakarya. 